\title{
Profile Number of Mice Takizoit after Treatment With Alkaloid Fraction of Alstonia scholaris Leaves
}

\author{
Abdul Hakim \\ Department of Pharmacy, Faculty of Science and Technology, Maulana Malik Ibrahim State \\ Islamic University of Malang, Indonesia \\ *Email : ahrizfit@gmail.com
}

\begin{abstract}
ABSTRAC
The prevalence of toxoplasmosis in Indonesia at 2006 was 43-88\%. Drugs that have been the most widely used for the treatment of patients with toxoplasmosis include pyrimethamine and spiramicin. However, these drugs have been reported to cause side effects such as bone marrow suppression, penetrate the blood brain barrier, crossed the placenta and fetal blood. Therefore necessary to find alternative drugs for toxoplasmosis effective and safe. This research studied the effect of alkaloid fraction of leaves of plants Alstonia scholaris to the number takizoit profiles in intraperitoneal fluid of mice infected with Toxoplasma gondii. This research used the experimental animals were grouped as the control group and the treatment group. In the treatment group, each group was given treatment with fraction extract alkaloids from leaves of plants Pulai. The results showed the number takizoit mice infected with Toxoplasma gondii parasites without therapy is $957.5 \times 103$ whereas the alkaloid fraction of the ethanol extract of leaves is $737.5 \times 103$.
\end{abstract}

Keywords: Leaves of Pulai (Alstonia scholaris), Toxoplasma gondii, toxoplasmosis.

\section{INTRODUCTION}

Toxoplasmosis is a serious zoonotic disease in animals and humans caused by the coccidian protozoan parasite Toxoplasma gondii groups [1]. The prevalence of toxoplasmosis in humans in Indonesia around 2-63\% [2] and increased to 43-88\% in 2006 [3]. Acute Toxoplasma gondii infection that infects a pregnant woman resulting in congenital toxoplasmosis in infants, as born with a disability, and death in the fetus resulting in miscarriage [4]. Drugs that have been the most widely used for therapy in patients with toxoplasmosis include pyrimethamine and spiramicin. Reported the synthesis of the drug can cause side effects such as bone marrow suppression, penetrate the blood brain barrier, crossed the placental and fetal blood [5]. Based on the above description it is necessary to develop the research effort and the search for drugs for toxoplasmosis minimal side effects for both mother and fetus, one of which is a plant Pulai (Alstonia scholaris).

Research on the effectiveness of the plants against parasites Toxoplasma gondii Pulai not much though research on the content of active compounds Pulai have enough detail. Kumolosasi [6] studied the potential of one of the island botanicals stem bark of A. scholaris as phytopharmaca preparation on the growth and development of the fetus associated toxoplasmosis. The results stated that the ethanol extract of the stem bark as a potential anti-toxoplasma island. In 2004, in his research Kumolosasi explained that Pulai extract dose of $490 \mathrm{mg} / \mathrm{kg} \mathrm{bw}$ and $980 \mathrm{mg} / \mathrm{kg}$ bw is the dose that can give teratogenic effects in Wistar rats, the results obtained lead to miscarriage at $9.1 \%$ each parent mice, mild hydrocephalus in 
$23.1 \%$ of fetuses (dose of $490 \mathrm{mg} / \mathrm{kg} \mathrm{bw}$ ) and $12 \%$ fetal (dose of $980 \mathrm{mg} / \mathrm{kg} \mathrm{bw}$ ). This prompted the researchers to conduct further research on the potential anti-toxoplasma Pulai as with lower dose of the teratogenic dose.

In this study, will be studied the effect of the alkaloid fraction of the leaves of Pulai to profile takizoit amount of intraperitoneal fluid in mice infected with Toxoplasma gondii.. The results of this study are expected to reinforce the notion of potential of Pulai leaf extracts against Toxoplasma gondii

\section{MATERIALS AND METHODS \\ Methodology}

Analysis of Water Levels (AOAC, 2005)

The first stage is carried out to analyze the moisture content is dry the porcelain dish in the oven at $105^{\circ} \mathrm{C}$ for 1 hour. The cup was placed in a desiccator (approximately 15 minutes) and left to cool and then weighed. The cup was weighed again until its weight is constant, 5 grams of leaf samples islands inserted into the cup, then dried in an oven at $105^{\circ} \mathrm{C}$ for 5 hours or until its weight is constant. After completion of the process and then the cup is placed in a desiccator and allowed to cool and then weighed again. Test the moisture content of each sample performed on wet and dry samples. Calculation of water content:

$\%$ Water content $=(\mathrm{B}-\mathrm{C}) /(\mathrm{B}-\mathrm{A}) \mathrm{x} 100 \%$.

\section{Remarks:}

$\mathrm{A}=$ weight of the empty cup $(\mathrm{g})$

$\mathrm{B}=$ weight of the cup that is filled with the sample $(\mathrm{g})$

$\mathrm{C}=$ weight of the cup with the dried sample $(\mathrm{g})$

\section{Sample Preparation}

Leaves of Alstonia scholaris cleaned from impurities that stick. Furthermore, cut into small pieces, dried by heating using indirect sunlight. Samples were crushed using a blender to form a powder, then the powder is filtered to produce 40-60 mesh powder is then stored in plastic containers.

\section{Extraction to Alstonia scholaris leaves}

The powder samples were weighed as much as 100 grams island and treatment is divided into two, each 50 grams for the maceration process. Extraction by maceration respectively using ethanol (1:10) for 24 hours. Assisted with shaker stirring for 3 hours, then filtered and the residue obtained was macerated again with ethanol, the same treatment until a colorless filtrate. Then filtered to obtain a residue (dregs) and the filtrate, and the residue discarded, ethanol extract obtained in pekatkan with rotary vacuum evaporator and flowing N2 gas. Set aside some concentrated extract as a crude extract. The rest of the concentrated extract obtained redissolved in $2 \% \mathrm{H} 2 \mathrm{SO} 4$ was added diethyl ether to remove fat. Furthermore, the fraction of diethyl ether removed, and the water fraction was basified with $25 \% \mathrm{NH} 4 \mathrm{OH}$ to pH 9-10 and extracted with chloroform until colorless and alkaloid extract obtained (samples).

\section{Anti-toxoplasma Activity Test by Takizoit Number Profile.}

This study used a murine (Mus musculus) strains Balb / C types 6-7 week-old female with an average weight of 20-30 g. Before treatment, mice were kept in a cage that is backed with sawdust and woven wire mesh as a cover. Feeding and drinking is done every day ad libitum. 


\section{Treatment of mice}

The study was conducted with six treatment groups. The number of samples from each treatment group was calculated using the formula Federer. Federer formula: $(n-1)(t-1) \geq 15$; with $\mathrm{t}=$ the number of groups $=5$

$\mathrm{n}=$ number of repetitions of each sample

$(\mathrm{n}-1)(5-1) \geq 15$

(n-1) $4 \geq 15$

$4 n-4 \geq 15$

$4 \mathrm{n} \geq 19$ then $\mathrm{n} \geq 4.75=5$

Based on the calculations above, the minimum number of samples required is five mice for each treatment group. The provisions of each group are as follows [7]:

1. Negative control group, the treatment group was infected by parasites Toxoplasma gondii strain RH non-dose treatment with $0.5 \mathrm{~mL}$ of $1 \% \mathrm{CMC}-\mathrm{Na}$.

2. Positive control group is the group of mice infected with drug administration pyrimetamine takizoit with a dose of $50 \mathrm{mg} / \mathrm{kg}$ bw once a day by mouth.

3. E1 treatment group was treated groups of mice infected with takizoit alkaloid extract from the ethanol extract of leaves of islands with a dose of $25 \mathrm{mg} / \mathrm{kg}$ bw once a day by mouth.

4. E2 group was treated groups of mice infected with takizoit alkaloid extract from the ethanol extract of leaves of islands with a dose of $50 \mathrm{mg} / \mathrm{kg}$ bw once a day by mouth.

5. E3 Group is a group of infected mice treated with the extract alkaloids takizoit of ethanol extract of leaves of islands with a dose dose $75 \mathrm{mg} / \mathrm{kg}$ bw once a day by mouth.

Treatment is done from zero day to eight day. Observation process of takizoit number observed in the negative control group where all are expected to die on day 5. Takizoit taken from intraperitoneal fluid and counted with a hemocytometer.

\section{RESULT AND DISCUSSION Analysis of Water Content}

The water content of a sample is closely related to sample quality and speed of sample damage, either chemical or microbiological nature. The results of the water content of the Pulai leaf shown in Table 1.

Table 1. The water content contained in the leaves of Alstonia scholaris (L) .R.Br)

\begin{tabular}{|c|c|}
\hline Sample & Water content $(\% \mathbf{b} / \mathbf{b})$ \\
\hline Fresh leaves & $68,90 \%$ \\
\hline Dry powder & $8,34 \%$ \\
\hline
\end{tabular}

These results indicate that the dried sample has a water content that meets the standards to be stored for a long time. This is consistent with the statement that the sample is said to be good and can be stored in the long term if it has a moisture content of less than $10 \%$, because at the level of the water content of the sample can be spared from the rapid growth of the fungus. 
Profile Number of Mice Takizoit after Treatment with Alkaloid Fraction of Alstonia scholaris

Takizoit observed using a microscope as shown in Figure 1.

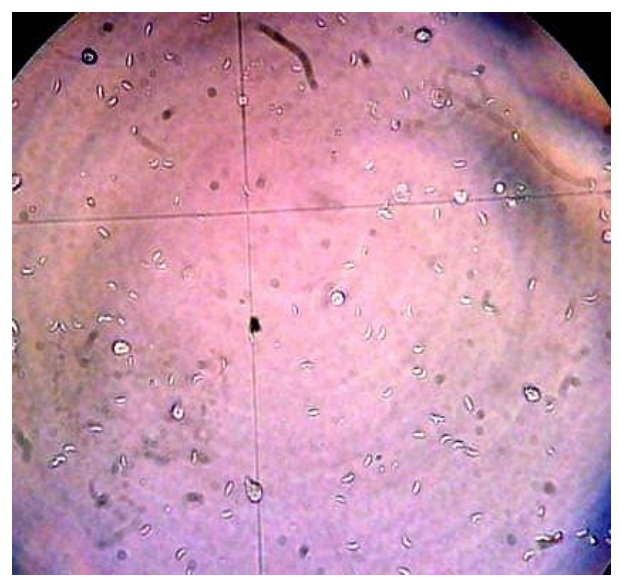

Fig 1. Observation using a microscope takizoit

The results of takizoit calculation are shown in Table 2:

Table 2, Calculation of the amount of the takizoit after treatment with alkoloid fraction of ethanol extract of the leaves of Alstonia scholaris (L.) R. Br).

\begin{tabular}{|c|c|}
\hline Treatment groups & Mean number of takizoit \\
\hline negatif control + CMC-Na 1\% & $957,5 \times 10^{3}$ \\
\hline positif control + drug & $702,5 \times 10^{3}$ \\
\hline $\begin{array}{c}\text { Ethanol extract with dose } 25 \\
\mathrm{mg} / \mathrm{Kg} \mathrm{BB}\end{array}$ & $737,5 \times 10^{3}$ \\
\hline
\end{tabular}

The above data indicate that the ethanol extract of leaves of Pulai has the ability to inhibit the rate of growth or development in mice infected takizoit, although capacity is still under positive control. It appears when seen takizoitnya number and compared to the number takizoit the untreated group, where the number takizoit therapy group was much smaller than the number takizoit negative control group.

\section{CONCLUSION}

Takizoit number of mice infected with Toxoplasma gondii parasites without therapy is $957.5 \mathrm{x}$ 103 while the alkaloid fraction of the ethanol extract of leaves is $737.5 \times 103$. It shows the ability of ethanol extract of the leaves of Pulai inhibit the development of takizoit and has the ability as anti-toxoplasma.

\section{ACKNOWLEDGEMENTS}

Thank you for all my colleagues that help me to finishing this research. 


\section{REFERENCES}

[1] Iskandar T., Didik T.S., Eka F. D. 2006. Gambaran Splenosit, Limpa dan Kekebalan pada Mencit Galur Balb/c Yang Diberi Alantoin dan Dinfeksi Toxoplasma gondii. Bogor. Seminar Nasional Teknologi Peternakan dan Veteriner.

[2] Susanto, L., Supali, T. dan Gandahusada. S. 2002, Kesehatan, Vol. 6, No. 2: 64-70.

[3] Subekti, D. T., dan Arrasyid, N, K. 2006, Wartazoa. Vol.6. No. 3: 128-145.

[4] JP Dubey, M. Louis Weiss, Toxoplasmosis: A History of Clinical Observations. Departments of Medicine (Division of Infectious Diseases) and Pathology (Division of Parasitology), AlbertEinstein College of Medicine, Animal Parasitic Diseases Laboratory, Animal and Natural Resources Institute Agricultural ResearchService, United States Department of Agriculture, 2009.

[5] Wibisono, D.S .2005. Ragam Medikamentosa Terapi Toksoplasmosis pada Kehamilan.SMF Kebidanan dan Penyakit Kandungan RSUP Fatmawati, Jakarta. Subbagian Immuno Endokrin Reproduksi Kebidanan FKUI-RSCM Jakarta.

[6] Kumolosasi E.., S. Elin Yulinah, W Komar Ruslan, US Andrenaus, Sundani Nurono, 1999, Making preparations Phytopharmaca Against Diseases Toxoplasmosis, caused by Toxoplasma gondii is Effective and Safe, Competitive Grant Research Report VII, ITB, Bandung.

[7] Subekti, D. T., dan Arrasyid, N, K. 2006, Wartazoa. Vol.6. No. 3: 128-145. 